\title{
Heavy Metals in Liver, Kidney, Brain and Muscle Slender-Billed Gull (Chroicocephalus Genei) From the Chahnimeh Water Reservoirs Sistan and Coast Oman Sea (Iran)
}

Reza Dahmardeh Behrooz ( $\sim$ dahmardeh_behrooz@yahoo.com )

Enviroment https://orcid.org/0000-0003-0933-2725

Joanna Burger

Rutgers University Board of Governors: Rutgers The State University of New Jersey

\section{Research Article}

Keywords: slender-billed gull, heavy metals, Sistan, Coast Oman Sea

Posted Date: February 9th, 2021

DOI: https://doi.org/10.21203/rs.3.rs-157124/v1

License: () (1) This work is licensed under a Creative Commons Attribution 4.0 International License. Read Full License 


\section{Abstract}

The concentrations of four heavy metals nickel ( $\mathrm{Ni})$, cadmium ( $\mathrm{Cd})$, lead $(\mathrm{Pb})$ and zinc $(\mathrm{Zn})$ were determined in liver, kidney, muscle and brain tissues of 20 slender-billed gulls (Chroicocephalus genei) from the Chahnimeh water reservoirs of Sistan and the Oman Sea coast of Iran. There were significant differences between nickel $\mathrm{Ni}, \mathrm{Cd}, \mathrm{Pb}$ and $\mathrm{Zn}$ concentrations observed in the liver and brains of birds from the Oman Sea coast than in liver and brains of gulls from the Chahnimeh water reservoirs $(\mathrm{P}<0.05)$. Higher levels of $\mathrm{Pb}, \mathrm{Cd}$ and $\mathrm{Zn}$ were found in the brain and liver of gulls than in the kidney and muscles tissues. There were significant gender differences in heavy metals in liver and brain tissue. In gulls from the coast of Oman Sea, all four elements (Cd, Pb, Ni and $\mathrm{Zn}$ ) were positively correlated with levels in all organs, and except for muscle, the elements were positively correlated with the other elements in the other tissue (except $\mathrm{Ni}$ in brain). Thus, the pathways and sources of entry for the elements are similar, and the pathways for accumulation of these elements, and the reactions of different organs of the body to these elements, are very similar. Also, $40 \%$ of gulls in Oman Sea coast had levels of lead in the brain that were above the adverse effects levels, Ni concentrations in liver of slender-billed gull in Oman Sea coast (100 \%) and Chahnimeh water reservoirs (90\%) were above toxic levels, and $80 \%$ of Ni concentration in kidneys in gulls from the Oman Sea coast and Chahnimeh water reservoirs were higher than the toxicity levels.

\section{Introduction}

Little is known about the metal contamination in birds or other organisms from much of Iran, either from biota inhabiting salt water or those living in freshwater habitats. Consequently, it is difficult to determine whether birds are exposed to toxic levels, how levels in birds from Iran compare to those in birds from elsewhere in the world, and whether birds are good bioindicators of environmental contamination. This paper compares metal contamination in gulls from interior freshwater systems (Chahnimeh Water Reservoirs) with levels from gulls living along the coast (Oman Sea Coast) of Iran, 700 km apart. Both are in the province of Sistan va Baluchestan, Iran.

Sistan va Baluchestan province is the largest province in Iran and has many salty and fresh water resources. One interior resource, named Zabol Chahnimeh, has four big natural cavities located in the south of the Sistan plain ( $35 \mathrm{Km}$ southe of Zabol city, $30^{\circ} 45^{\prime}$ to $30^{\circ} 50^{\prime} \mathrm{N}$; $61^{\circ} 38^{\prime}$ to $61^{\circ} 45^{\prime} \mathrm{E}$ ); it spans an area of 100 million square meters, with 1500 million $/ \mathrm{m}^{3}$ volume (Fig. 1). Waters from the Helmand River are stored in these natural cavities, and with the onset of the 2005 drought in the Sistan region, these water reservoirs are the only water source to fill the drinking water needs of Zahedan and Zabol cities, as well as the agricultural needs of the Sistan region. With the onset of this drought, and the drying down of the Halmand International Wetlands, the remaining water resources are the only water sources for birds and aquatic organisms. Further, the Chahnimeh Water Reservoirs (CWR) on the Helmand River are the only source of water for the cities in the Sistan region. The Helmand River is the longest freshwater river in Afghanistan; it originates from the Babayaghma Mountains near Kabul city. After joining the Arqand and Lura Rivers near Kandahar city (after $1100 \mathrm{~km}$ ), it enters Iran and the Sistan region, and finally ends at the CWR and the Halmand International Wetland. In Afghanistan, there is the Kajaki dam, and the river passes through many villages and cities, many agricultural lands, and many factories. Increasing the number of factories and industries along the Helmand River in Afghanistan increased the possibility of river pollution, especially from rural agricultural sewage (Dahmardeh Behrooz et al. 2013).

To the south, the Oman Sea Coast (OSC), near the Chabahar seaport in Sistan va Baluchestan province, is one of the most important, developed areas in this province. The development of human activities along the OSC has caused these beaches to be exposed to pollution, especially from heavy metals [2]. The most important sources of pollution are marine transportation, and the discharge of water by boats and ships, urban wastewater from Chabahar city, wastewater upstream from the Tiss Shahid Beheshti and Shahid Kalantari ports, food and factory discharges, and agricultural land sewage (Amini-Ranjbar and Miraki 2006).

We measured levels of cadmium (Cd), lead (Pb), nickel (Ni) and zinc ( $\mathrm{Zn}$ ) in tissue of slender-billed gull (SBG) (Chroicocephalus genei) in CWR and OSC from Iran. The objectives of this study are: 1) to monitor heavy metals contamination in the CWR and OSC areas to aid in development of a protection plan for this species and these regions, 2) to investigate heavy metals in various tissue of gulls to determine the best organs to use as a bioindicator for changes in heavy metal exposures, and 3) to examine the relationship between heavy metals and sources of pollution in these areas.

Heavy metals have toxic and long-lasting effects on the environment, pose a significant threat to ecosystems, and can lead to ecosystem degradation (Zhang et al. 2018). Cd and Pb are very toxic and non-essential elements in the body. If $\mathrm{Cd}$ is absorbed by the body through the digestive and pulmonary systems, it combines with a set of proteins to transport and store Cd in the liver of organisms (Szymczyk and Zalewski 2003). Pb can also have long-term effects on birds' organs and tissues if absorbed by birds (Beyer \& Meador 2011). Zn is an essential element in the body of birds, but high levels of Zn can lead to poisoning and damage to the liver and pancreas tissues of birds (Kalisińska et al. 2007).

The level of contamination increases with increased trophic level; species that are higher on the food chain have increased bioaccumulation (Ullah et al. 2014). Indicator species are used to assess the effects of contaminations, and wild birds are important indicators because they forage on a range of food sources (Erwin and Custer 2000). Birds are widely distributed and occupy a high trophic level on the food chain (Barbieri et al. 2010). Among seabirds, gull species are top-level predators, are highly sensitive to toxic elements, have a wide geographical distribution, have been used as bioindicators, and are easy to sample (Savinov et al. 2003; Braune and Simon 2004; Malinga et al. 2010; NERGiZ 2019). Gulls often live close to humans and industry, human garbage forms a large part of their diet, and levels of contaminants can be compared to other seabirds, such as P. carbo, U. lomvia, S. mollissima, and albatrosses (Vizuete et al. 2018).

\section{Materials And Methods} 2.1. Collection of samples 
Twenty individual slender-billed gulls (SBG) were purchased from fishermen in the CWR $(n=20)$ and OSC $(n=20)$ during February and March, 2019 (Fig. 1). Birds were weighed and stored in plastic bags that were previously cleaned with acetone and water. Samples were kept at $-20^{\circ} \mathrm{C}$ until dissection and analysis.

\subsection{Analytical procedure}

Birds were thawed, and liver, kidney, brain and pectoral muscle tissues were collected. Samples (1 to $3 \mathrm{~g}$ wet weight) were placed into Erlenmeyer flasks with $150 \mathrm{Ml}$, ten $\mathrm{mL} 65 \% \mathrm{HNO}_{3}$ (Suprapure, Merck, Darmstadt, Germany) was added to the Erlenmeyer flasks, and was slowly digested overnight after five mL $\mathrm{HClO} \otimes, 70 \%$ was added to each sample (Suprapure, Merck, Darmstadt, Germany) (Mansouri et al. 2012a). For digestion we used a hot plate (sand bath) at the first step at $200^{\circ} \mathrm{C}$, for about $6 \mathrm{~h}$ or until the solutions were clear after cooling, and in the second step each sample was transferred to polyethylene bottles and deionized water was added until the sample equaled $25 \mathrm{~mL}$. In each set of eight samples, one control sample was prepared and examined. Then the solution was filtered using a $0.45 \mu \mathrm{m}$ nitrocellulose membrane filter. A Shimadzu AA 680 flame atomic absorption spectrophotometer was used for determining the concentrations of heavy metals. The detection limits for $\mathrm{Cd}, \mathrm{Pb}, \mathrm{Ni}$ and $\mathrm{Zn}$ were $0.09,0.04,0.06$ and $0.09 \mu \mathrm{g} / \mathrm{g}$ respectively. The obtained recoveries for $\mathrm{Cd}, \mathrm{Pb}$, $\mathrm{Ni}$ and $\mathrm{Zn}$ averaged from $88 \%$ to $105 \%$.

\subsection{Quality Control}

Procedural blanks and certified reference material (CRMs, e.g. DOLT-2 and DORM-2) were included in each sample batch. To determine the detection limit of heavy metals in the samples, blank samples were injected three times for analysis and the result with 3-times the standard deviation of the procedural blanks $(0.08,0.05,0.07 \mu \mathrm{g} / \mathrm{g} \mathrm{dw}$ and $0.1 \mathrm{in} \mathrm{Cd}, \mathrm{Ni}, \mathrm{Pb}$ and $\mathrm{Zn}$ respectively). The precision and accuracy of the applied analytical method was determined based on CRMs, e.g. DOLT-2 and DORM-2 heavy metal in sample. The results of our CRMs measurements were a good estimate of the real values. In each sample batch, procedural blanks and certified reference material DOLT-2 and DORM-2 were included. For each matrix, analyses of three blank samples and analysis of reagent blanks was performed. In order to estimate the accuracy and precision of the chemical analysis; sample blanks, standard blanks and three analytical duplicates with the concentration of $1.2 \mu \mathrm{g} / \mathrm{g}$ were injected and their mean and its $95 \%$ confidence interval was calculated. Quantification was based on multilevel calibration on the concentrations of $0.1,0.5,3,15,50$ and $100 \mu \mathrm{g} / \mathrm{g}$; and then the standard calibration curve was drawn with $99 \%$ accuracy. All concentrations are expressed in $\mu \mathrm{g} \mathrm{g}^{-1}$ of d.w.

\subsection{Statistical analysis}

For data analysis we used SPSS (Version 20.0). The data were tested for normality using a Kolmogorov-Smirnov test. For determination of normal distribution and homogeneity of variance of heavy metals levels in the tissue samples, we used the Kolmogorov-Smirnov test and after normalizing the data, we used parametric statistics. To test differences in total heavy metals levels among groups we performed a one-way ANOVA, and then applied the Duncan's post hoc test for differences in levels between areas. Differences in total heavy metals levels between the two regions were determined by an independent $t$ test. Spearman's rank correlation coefficients were used to test for correlations among various heavy metals. A p value $<0.05$ was considered to indicate statistical significance.

\section{Results And Discussion}

The median levels of $\mathrm{Zn}, \mathrm{Pb}$ and $\mathrm{Cd}$ in the tissues of SBG were (in decreasing order): brain $>$ liver $>$ muscle $>$ kidney (OSC), and brain $>$ liver $>$ kidney $>$ muscle (CWR). There was a significant difference $(\mathrm{P}<0.05)$ in $\mathrm{Zn}, \mathrm{Pb}$ and $\mathrm{Cd}$ concentration between brain and liver compared to kidney and muscles in gulls of $\mathrm{OCS}$ (Fig. 2). The median concentration of $\mathrm{Ni}$ in the tissues differed and was (in decreasing order): liver $>$ kidney $>$ muscle $>$ brain (OSC) and liver $>$ muscle $>$ kidney $>$ brain ((CWR). There was a significant difference in the Ni level between the brain and the liver, kidney, and muscle $(P<0.05)($ Fig. 2).

The levels of heavy metals in muscle tissue were lower than in other tissues, and our results agree with other studies that reported that muscle tissue does not accumulate these four heavy metals. Also, in this study the brains of gulls had the highest concentration of metals, except Ni $(P<0.05)$. Analysis of heavy metals in the internal organs of birds allows for assessment of environmental pollution. The level of metal a body absorbs and accumulates depends on the level of exposure, the chemical form of an element, the interaction among elements, and physiological factors of the bird species (Gochfeld and Burger 1987). Accumulation of pollutants in the internal organs of their bodies is greatly affected by the contaminant level of the food and water ingested. Liver and kidney are sites of detoxification, reflect long-term bioaccumulation, and experience long periods during which they have accumulated metals (Burger and Gochfeld 2016), while muscle and brain are sites of accumulation, but not of detoxification (Janaydeh et al. 2016) Other studies show that levels of $\mathrm{Pb}$ in liver and brain increase with age, and this can be due to accumulation as $\mathrm{Pb}$ complexes with metallothioneins, resulting in a long half-life (Zaccaroni et al. 2003).

If birds are exposed to high concentrations of $\mathrm{Pb}$ and $\mathrm{Cd}$, these elements can accumulate in high concentrations in the brains of these birds, such as in whitetailed eagle (Haliaeetus albicilla) of and scavenging gulls; brain tissue levels were related to dietary contamination (Hulse et al. 1980; Szefer and Falandysz 1987). Similar to the results in our study, the levels of $\mathrm{Pb}$ and $\mathrm{Cd}$ in some bird species at high trophic levels had high levels in their brain tissue (Grue et al., 1986; Morris et al., 1992; Rice, 1992; Vaneeden and Schoonbee, 1992a). Relatively low (up to 0.4 ppm wet wt) Pb, but not Cd levels, were recorded in the brain of pelagic seabirds (Morris et al. 1992; Rice 1992). Redknobbed coots (Fulica cristata) from industrialized and polluted region of South Africa had Pb levels in brain that increased to $25 \mathrm{ppm}$ (dry weight), 2 and 4 times as much as in kidneys and liver (Vaneeden and Schoonbee 1992b). These studies on the accumulation of heavy metals in the brain of birds should be further compared to other organs of the body. Different adaptations of birds to the environment, as well as the reaction and function of the brain against different contaminants, can be one of the factors affecting the absorption of contaminants in birds' brains. There are few studies of the levels of heavy metals in the brain tissues of birds, and this requires further investigation.

Significant differences in levels of $\mathrm{Ni}, \mathrm{Cd}, \mathrm{Pb}$ and $\mathrm{Zn}$ concentrations were observed between the liver and brains of birds of the OCS and those of birds in the CWR (Table 1 and Fig. 1). Gulls of the OSC had significant and positive correlations among concentrations of $\mathrm{Cd}, \mathrm{Ni}, \mathrm{Pb}$ and $\mathrm{Zn}$ in the kidney, liver and brain 
tissue (but not Cd in the brain) (Table 2). On the contrary, all elements in each of the tissues in gulls from the OSC were positively correlated with each other (Table 2).

Table 1

Mean, median, minimum and maximum ( $\mu \mathrm{g} / \mathrm{g} \mathrm{d} . \mathrm{w})$ in Liver, kidney, brain and muscle of of slender-billed gull (Chroicocephalus genei) from the Chahnimeh w reservoirs of Sistan and Coast Oman Sea from Iran.

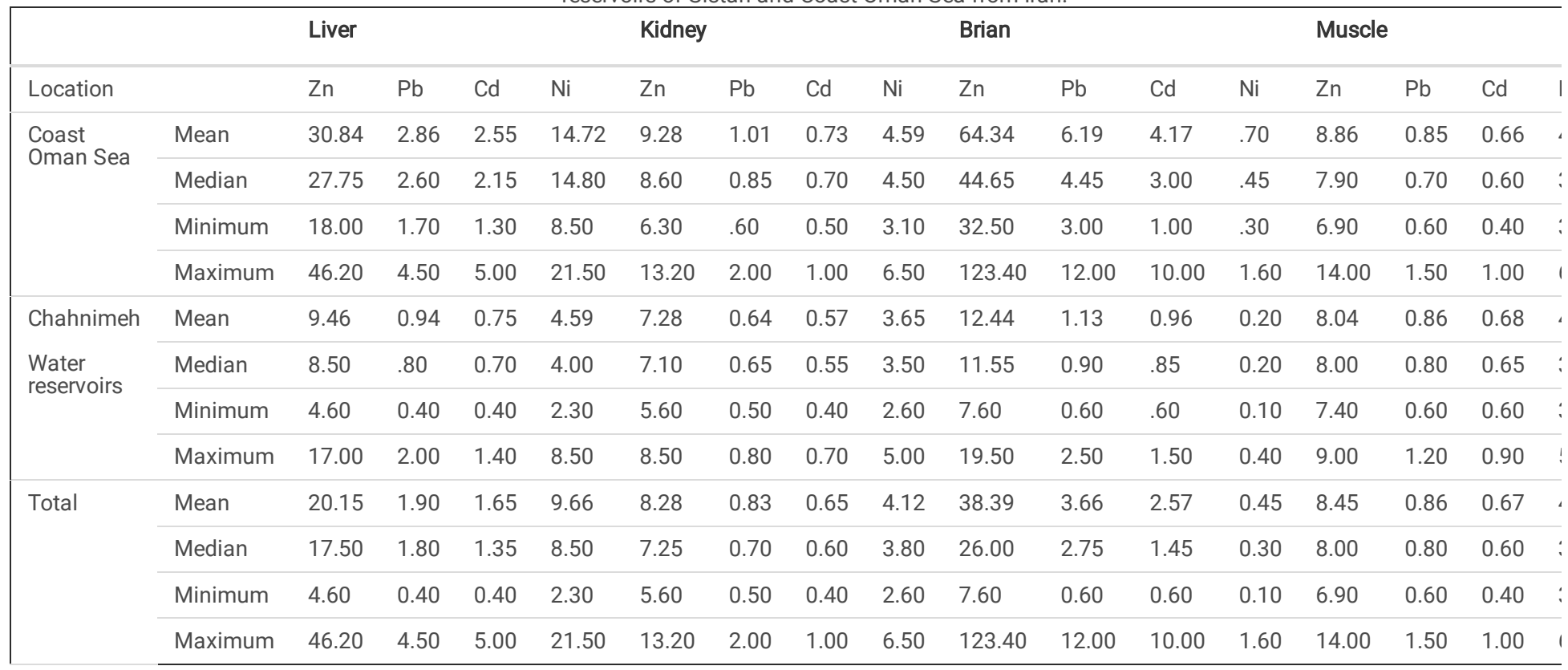

Gulls of the CWR, unlike birds on the OSC, had high correlations between elements with each other in any tissue, and within different tissues. In CWR birds, there were correlations among tissues for $\mathrm{Cd}, \mathrm{Pb}$ and $\mathrm{Zn}$ in liver and brain tissues. There was also a correlation between the concentrations of $\mathrm{Zn}$ in the kidneys with $\mathrm{Ni}$ in the brain, $\mathrm{Pb}$ in the kidneys, $\mathrm{Cd}$ in the muscles; $\mathrm{Cd}$ in kidney was correlation with $\mathrm{Ni}$ in the brain and $\mathrm{Zn}$ with muscle, and $\mathrm{Ni}$ in kidney was correlated with $\mathrm{Ni}$ in the brain. $\mathrm{Cd}, \mathrm{Pb}$ and $\mathrm{Zn}$ had the highest positive correlations with each other in liver, muscle, kidney and brain tissues; this shows that the sources of these elements in CWR are the same, but unlike the OSC, the food resources used by gulls do not contain high levels of heavy metals.

The high level of heavy metals in gulls of the OCS is due to various industrial activities in this region, the most important being repairing and painting fishing vessels, as well as releasing grease from repairing the engines of these ships on the shores (Hamzeh et al. 2013). The paints used on the surface under the fishing vessels to prevent the development of algae and barnacles contain copper and Zn; 15 to 30\% of the paint used is copper and Zn (Orlić and Tang 1999). Grease disposal from repaired ship engines also contains metals such as $\mathrm{Fe}, \mathrm{Ni}, \mathrm{Zn}, \mathrm{Cu}, \mathrm{Zn}$, and $\mathrm{Pb}$, which increases metal contamination off the coast of the region (Hamzeh et al. 2013). The high level of heavy metals in an area are often related to the activities of factories and their disposal, but there is not much industrial activity in this area, so the high concentration of heavy metals must have other sources in addition to those mentioned. Previous studies in this area indicate that the high concentration of heavy metals is due to natural erosion and the transport of sediments containing high concentrations of heavy metals that originate from the Makran mountains by local rivers such as the Bahukalat River (Hamzeh et al. 2013). In addition, human activities such as restaurants, tourism, and domestic sewage near the shoreline are other sources of heavy metals in this area (Einollahi Peer et al. 2010) .

Unlike the OSC, in CWR the only source of heavy metals is agricultural activities, including the use of chemical fertilizers and pesticides around the Helmand River in Afghanistan and Iran, which are the only source of power for CWR (Dahmardeh Behrooz et al. 2013).

\subsection{Hazard evaluation and comparisons with other sites}

Reports of Zn toxicity for wild birds in liver are > $122 \mathrm{ng} / \mathrm{g} \mathrm{dw}$ (Gomez et al. 2004), > $440 \mathrm{n} / \mathrm{g} \mathrm{dw}$, (Beyer et al. 2004) and 700-1830 ng/g (dw)(Sileo et al. 2003). $\mathrm{Zn}$ levels in this study were lower than these $\mathrm{Zn}$ toxic level for wild birds. The normal level of $\mathrm{Zn}$ in the liver of mammals and birds usually does not exceed $525.0 \mathrm{\mu g} / \mathrm{g} \mathrm{dw}$ (Taggart et al. 2009) and our results show that none of the gulls in the OSC and CWR were above that level. The concentrations of Zn in the liver, kidney and muscle tissues of CWR and OSR gulls were lower than the others gulls reported from other parts of the world, and only the concentrations of $\mathrm{Zn}$ in kidney of gulls from the OSR was higher than in coastal areas of Italy (Leonzio et al. 1986) (Table 3). The level Zn in gull of Rishiri Island, Japan was 60 $\mu \mathrm{g} / \mathrm{g}$ d.w (Agusa et al. 2005) while the level of $\mathrm{Zn}$ in the brain of OSR and CWR gulls was 64.34 and $12.44 \mu \mathrm{g} / \mathrm{g}$ d.w re, respectively.

Table 2. Correlation coefficient ( $r$ ) between the concentrations of trace element in the liver, kidney, brain and muscles of slender-billed gull from the Chahnimeh water reservoirs of Sistan and Coast Oman Sea from Iran. 


\begin{tabular}{|c|c|c|c|c|c|c|c|c|c|c|c|c|c|c|}
\hline & $\begin{array}{l}\text { Zn } \\
\text { liver }\end{array}$ & $\begin{array}{l}\mathrm{Pb} \\
\text { liver }\end{array}$ & $\begin{array}{l}\mathrm{Pb} \\
\text { liver }\end{array}$ & $\begin{array}{l}\mathrm{Ni} \\
\text { Liver }\end{array}$ & $\begin{array}{l}\text { Zn } \\
\text { kidney }\end{array}$ & $\begin{array}{l}\mathrm{Pb} \\
\text { Kidney }\end{array}$ & $\begin{array}{l}\text { Cd } \\
\text { Kidney }\end{array}$ & $\begin{array}{l}\mathrm{Ni} \\
\text { Kidney }\end{array}$ & $\begin{array}{l}\text { Zn } \\
\text { Brian }\end{array}$ & $\begin{array}{l}\mathrm{Pb} \\
\text { Brian }\end{array}$ & $\begin{array}{l}\text { Cd } \\
\text { Brian }\end{array}$ & $\begin{array}{l}\mathrm{Ni} \\
\text { Brian }\end{array}$ & $\begin{array}{l}\text { Zn } \\
\text { Muscle }\end{array}$ & $\begin{array}{l}\mathrm{Pb} \\
\text { Muscle }\end{array}$ \\
\hline $\begin{array}{l}\text { Zn } \\
\text { liver }\end{array}$ & 1 & $0.937^{\star \star}$ & $0.952^{\star \star}$ & $0.958^{\star *}$ & $0.954^{\star *}$ & $0.880^{\star *}$ & $0.940^{\star *}$ & $0.955^{\star *}$ & $0.918^{\star *}$ & $0.895^{\star *}$ & NS & $0.932^{\star \star}$ & NS & NS \\
\hline $\begin{array}{l}\mathrm{Pb} \\
\text { Liver }\end{array}$ & $0.970^{\star \star}$ & 1 & $0.865^{\star \star}$ & $0.862^{\text {** }}$ & $0.822^{\star *}$ & $0.831^{\star \star}$ & $0.869^{\star *}$ & $0.860^{\star \star}$ & $0.934^{\star *}$ & $0.933^{* *}$ & NS & $0.912^{* *}$ & NS & NS \\
\hline $\begin{array}{l}\text { Cd } \\
\text { Liver }\end{array}$ & $0.978^{\star *}$ & $0.997^{\star *}$ & 1 & $0.913^{\star *}$ & $0.908^{\star *}$ & $0.836^{* *}$ & $0.912^{\star *}$ & $0.906^{\star *}$ & $0.874^{\star *}$ & $0.856^{\star *}$ & NS & $0.948^{* \star}$ & NS & NS \\
\hline $\begin{array}{l}\mathrm{Ni} \\
\text { Liver }\end{array}$ & $0.988^{\star \star}$ & $0.981^{\star *}$ & $0.985^{\star \star}$ & 1 & $0.928^{\star *}$ & $0.787^{\star \star}$ & $0.923^{\star \star}$ & $0.947^{\star \star}$ & $0.834^{\star *}$ & $0.796^{* *}$ & NS & $0.840^{\star \star}$ & NS & NS \\
\hline $\begin{array}{l}\text { Zn } \\
\text { Kidney }\end{array}$ & NS & NS & NS & NS & 1 & $0.902^{\star *}$ & $0.963^{* *}$ & $0.980^{* *}$ & $0.853^{\star \star}$ & $0.830^{\star \star}$ & NS & $0.886^{\star \star}$ & NS & NS \\
\hline $\begin{array}{l}\mathrm{Pb} \\
\text { Kidney }\end{array}$ & NS & NS & NS & NS & $0.819^{\star \star}$ & 1 & $0.920^{\star \star}$ & $0.918^{\star *}$ & $0.816^{\star *}$ & $0.824^{* *}$ & NS & $0.871^{\star \star}$ & NS & NS \\
\hline $\begin{array}{l}\text { Cd } \\
\text { Kidney }\end{array}$ & NS & NS & NS & NS & $0.645^{\star}$ & NS & 1 & $0.985^{\star \star}$ & $0.871^{\star \star}$ & $0.871^{\star *}$ & NS & $0.912^{* *}$ & NS & NS \\
\hline $\begin{array}{l}\mathrm{Ni} \\
\text { Kidney }\end{array}$ & NS & NS & NS & NS & $0.892^{* *}$ & $0.787^{\star \star}$ & $0.725^{\star}$ & 1 & $0.851^{\star *}$ & $0.833^{\star \star}$ & NS & $0.884^{\star \star}$ & NS & NS \\
\hline $\begin{array}{l}\text { Zn } \\
\text { Brian }\end{array}$ & $0.985^{\star *}$ & $0.968^{* *}$ & $0.971^{\star *}$ & $0.973^{* *}$ & NS & NS & NS & NS & 1 & $0.991^{\star \star}$ & NS & $0.966^{* \star}$ & NS & NS \\
\hline $\begin{array}{l}\mathrm{Pb} \\
\text { Brian }\end{array}$ & $0.960^{\star \star}$ & $0.982^{* *}$ & $0.981^{* *}$ & $0.981^{\star *}$ & NS & NS & NS & NS & $0.937^{\star \star}$ & 1 & NS & $0.967^{\star \star}$ & NS & NS \\
\hline $\begin{array}{l}\text { Cd } \\
\text { Brian }\end{array}$ & $0.930^{\star \star}$ & $0.907^{\star \star}$ & $0.920^{\star \star}$ & $0.910^{\star \star}$ & NS & NS & NS & NS & $0.944^{\star \star}$ & $0.889^{\star \star}$ & 1 & 0.534 & NS & NS \\
\hline $\begin{array}{l}\mathrm{Ni} \\
\text { Brian }\end{array}$ & NS & NS & NS & NS & $0.633^{\star}$ & 0.546 & $0.697^{\star}$ & $0.767^{\star \star}$ & NS & NS & NS & 1 & NS & NS \\
\hline $\begin{array}{l}\text { Zn } \\
\text { Muscle }\end{array}$ & NS & NS & NS & NS & NS & 0.191 & $0.652^{\star}$ & 0.216 & NS & NS & NS & NS & 1 & $0.956^{\star \star}$ \\
\hline $\begin{array}{l}\mathrm{Pb} \\
\text { Muscle }\end{array}$ & NS & NS & NS & NS & NS & 0.312 & NS & NS & NS & NS & NS & NS & $0.642^{*}$ & 1 \\
\hline $\begin{array}{l}\text { Cd } \\
\text { Muscle }\end{array}$ & NS & NS & NS & NS & NS & $0.757^{\star}$ & NS & NS & NS & NS & NS & NS & NS & $0.688^{*}$ \\
\hline $\begin{array}{l}\mathrm{Ni} \\
\text { Muscle }\end{array}$ & NS & NS & NS & NS & NS & 0.192 & NS & NS & NS & NS & NS & NS & $0.969^{\star \star}$ & $0.647^{*}$ \\
\hline
\end{tabular}

NS not significant $\quad * \mathrm{P}<0.05 \quad * *<0.01$

Table 3 Worldwide comparison mean concentration $(\mu \mathrm{g} / \mathrm{g}$ d.w) of $\mathrm{Cd}, \mathrm{Pb}$, Ni and $\mathrm{Zn}$ in slender-billed gull OCS and CWR in Iran the other species gulls in various countries 


\begin{tabular}{|c|c|c|c|c|c|c|c|c|c|c|c|c|c|}
\hline & Location & Reference & Date & $\mathrm{Cd}$ & & & & $\mathrm{Pb}$ & & & & $\mathrm{Ni}$ & \\
\hline \multirow[t]{3}{*}{ Species } & & & & Liver & Kidney & Brain & Muscle & Liver & Kidney & Brain & Muscle & Liver & Kidney \\
\hline & $\begin{array}{l}\text { OSR this } \\
\text { study }\end{array}$ & & & 2.55 & 0.73 & 4.17 & 0.66 & 2.86 & 1.01 & 6.19 & 0.85 & 14.72 & 4.59 \\
\hline & $\begin{array}{l}\text { CWR this } \\
\text { study }\end{array}$ & & & 0.75 & 0.57 & 0.96 & 0.68 & 0.94 & 0.64 & 1.13 & 0.86 & 4.59 & 3.65 \\
\hline \multirow[t]{2}{*}{ Sibria gull } & $\begin{array}{l}\text { Hara } \\
\text { biosphere } \\
\text { reserve }\end{array}$ & $\begin{array}{l}\text { (Hoshyari } \\
\text { et al. } \\
2012 \text { ) }\end{array}$ & $\begin{array}{l}\text { November } \\
\text { to } \\
\text { December } \\
2010\end{array}$ & 0.8 & 2.2 & - & 1.1 & 5.1 & 8.8 & & 3.4 & & \\
\hline & $\begin{array}{l}\text { Hara } \\
\text { biosphere } \\
\text { reserve }\end{array}$ & $\begin{array}{l}\text { (Mansouri } \\
\text { et al. } \\
2012 b \text { ) }\end{array}$ & $\begin{array}{l}\text { November } \\
\text { to } \\
\text { December } \\
2010\end{array}$ & & & & & & & & & 2.27 & 1.32 \\
\hline \multirow[t]{3}{*}{ L.argentatus } & $\begin{array}{l}\text { Gull Island } \\
\text { (Italy) }\end{array}$ & $\begin{array}{l}\text { (Elliott et } \\
\text { al. 1992) }\end{array}$ & 1992 & 3.6 & 34 & & & 0.69 & & & & & \\
\hline & $\begin{array}{l}\text { Kent Island } \\
\text { (Italy) }\end{array}$ & & 1992 & 5.4 & 40 & & & 0.24 & & & & & \\
\hline & $\begin{array}{l}\text { Mana Island } \\
\text { (Italy) }\end{array}$ & & 1992 & 13 & & & & 1.3 & & & & & \\
\hline \multirow[t]{4}{*}{ L.argentatus } & $\begin{array}{l}\text { Inland dump } \\
1 \text { (Italy) }\end{array}$ & $\begin{array}{l}\text { (Leonzio } \\
\text { et al. } \\
1986 \text { ) }\end{array}$ & $\begin{array}{l}\text { winter } \\
1984, \\
1985\end{array}$ & 0.085 & & 6.02 & $<0.02$ & & 3.95 & n.d & n.d & & \\
\hline & $\begin{array}{l}\text { Coastal area } \\
\text { (Italy) }\end{array}$ & & $\begin{array}{l}\text { winter } \\
1984 \\
1985\end{array}$ & 0.73 & & & & 1.82 & 3.75 & & & & \\
\hline & $\begin{array}{l}\text { Coastal area } \\
\text { (Italy) }\end{array}$ & & $\begin{array}{l}\text { winter } \\
1984 \\
1985\end{array}$ & 3.54 & 8.26 & & 0.31 & 3.78 & 3.4 & & 2.4 & & \\
\hline & $\begin{array}{l}\text { Inland dump } \\
2 \text { (Italy) }\end{array}$ & & $\begin{array}{l}\text { winter } \\
1984 \\
1985\end{array}$ & 1.91 & 4.5 & 0.16 & 0.22 & 3.30 & 13.25 & 0.85 & 2.05 & & \\
\hline L.argentatus & $\begin{array}{l}\text { Chaun, } \\
\text { northeast } \\
\text { Siberia, } \\
\text { Russia }\end{array}$ & $\begin{array}{l}\text { (Kim et al. } \\
\text { 1996) }\end{array}$ & $\begin{array}{l}\text { June-July } \\
1993\end{array}$ & 26.3 & 159 & & 0.91 & & & & & & \\
\hline \multirow[t]{2}{*}{ L.atricilla } & $\begin{array}{l}\text { International } \\
\text { Airport, } \\
\text { Queens } \\
\text { County, }\end{array}$ & $\begin{array}{l}\text { (Gochfeld } \\
\text { et al. } \\
1996 \text { ) }\end{array}$ & $\begin{array}{l}\text { May } \\
\text { through } \\
\text { Au- gust } \\
\text { of } 1992\end{array}$ & 0.87 & 2.44 & & 36.5 & 0.58 & 2.19 & & & & \\
\hline & New York & & & & & & & & & & & & \\
\hline L.crassirostris & $\begin{array}{l}\text { Rishiri } \\
\text { Island, } \\
\text { Japan }\end{array}$ & $\begin{array}{l}\text { (Agusa et } \\
\text { al. 2005) }\end{array}$ & $\begin{array}{l}\text { June } \\
1999, \\
2000 \text {, and } \\
2001\end{array}$ & 10.3 & 99.6 & 0.194 & 0.65 & 0.02 & 0.15 & 0.54 & 0.011 & & \\
\hline L.hyperboreus & $\begin{array}{l}\text { Akpatok } \\
\text { Island } \\
\text { (Canada) }\end{array}$ & $\begin{array}{l}\text { (Braune et } \\
\text { al. 2008) }\end{array}$ & $\begin{array}{l}\text { during the } \\
1983 \text { and } \\
1991 \text { to } \\
1993\end{array}$ & 17.4 & 90.3 & & & n.d & & & & & \\
\hline L.hyperboreus & $\begin{array}{l}\text { Coats Island } \\
\text { (Canada) }\end{array}$ & $\begin{array}{l}\text { (Braune et } \\
\text { al. 2008) }\end{array}$ & $\begin{array}{l}\text { during the } \\
1983 \text { and } \\
1991 \text { to } \\
1993\end{array}$ & 8.51 & 79.8 & & & n.d & & & & & \\
\hline L.ridibundus & $\begin{array}{l}\text { South - } \\
\text { Western } \\
\text { (Poland) }\end{array}$ & $\begin{array}{l}\text { (Orlowski } \\
\text { et al. } \\
2008)\end{array}$ & $\begin{array}{l}\text { June and } \\
\text { July } 2003\end{array}$ & 5.52 & 8.33 & 0.84 & 0.31 & 8.91 & 11.11 & 23.58 & 3.59 & & \\
\hline L.argentatus & $\begin{array}{l}\text { East coast } \\
\text { of Scotland } \\
\text { (U.K) } 1980\end{array}$ & $\begin{array}{l}\text { (Nicholson } \\
\text { 1981) }\end{array}$ & $\begin{array}{l}\text { during } \\
\text { June } \\
1977\end{array}$ & 1.86 & 13.7 & & n.d & & & & & & \\
\hline
\end{tabular}

nd $=$ non detected

Concentrations of $\mathrm{Cd}>3 \mu \mathrm{g} / \mathrm{g}$ d.w. and $>8 \mu \mathrm{g} / \mathrm{g}$ d.w in liver and kidney suggest hazardous environmental exposure (Scheuhammer 1987), and levels greater than $40 \mu \mathrm{g} / \mathrm{g}$ d.w. and $100 \mu \mathrm{g} / \mathrm{g}$ d.w in the liver and kidney indicate toxicities (Degernes 2008). Our results show that none of the gulls in OSC and CWR were above this toxicity level. 
The level of Cd in the liver and kidney of gulls from the OSC and CWR was low, and the level of Cd in the tissue of kidneys in the OSC and CWR was less than in other birds in the world (Table 3). However, the levels of Cd in the liver of CWR birds was higher than an inland dump in Italy (Leonzi 1986), and the level of Cd in the birds of OSR was higher than the birds of the inland dump (location \# 1 and \# 2) and the coastal area of Italy (Leonzio et al. 1986), and the gulls from the International Airport, Queens County, New York (USA) (Gochfeld et al. 1996). There are few studies comparing Cd in the brain tissue of gulls in other parts of the world. The level of Cd in the brain tissue of OSC and CWR was lower than inland dump (\# 1) and higher than the inland dump (\# 2) in Italy (Leonzio et al. 1986) and South - Western of Poland (Orlowski et al. 2008). Cd was more abundant in OSC and CWR than in the Coastal area, Inland dump 1, 2 (Italy) (Leonzio et al. 1986), Rishiri Island (Japan) (Agusa et al. 2005), South -Western (Poland) (Orlowski et al. 2008) and lower than in International Airport, Queens County, New York (USA) (Gochfeld et al. 1996) and Chaun, northeast Siberia (Russia) (Kim et al. 1996) (Table 3).

The threshold level for toxic exposure to $\mathrm{Pb}$ in liver and kidney of birds is $>6 \mu \mathrm{g} / \mathrm{g}$ dw weight (Clark and Scheuhammer 2003). In this study, none of the levels of $\mathrm{Pb}$ in the liver and kidney were higher than the toxic limit threshold. In birds, $\mathrm{Pb}$ concentrations in the brain $>5 \mathrm{ng} / \mathrm{g} \mathrm{d}$. w. are indicative of poisoning (Kalisinska 2000), and concentrations $>16 \mathrm{ng} / \mathrm{g} \mathrm{dw}$ indicate an advanced state of exposure in birds (Havera et al. 1992). In this study, 40\% of gulls in OSC had levels of $\mathrm{Pb}$ that were higher than the threat level of exposure to $\mathrm{Pb}$ in brain ( 5.5 to $12 \mathrm{ng} / \mathrm{g}$ dry weight).

$\mathrm{Pb}$ was lower in the kidney tissues of OSC and CWR gulls than for other gulls, except for those from Rishiri Island, Japan (Agusa et al. 2005). Pb levels in the brains of gulls in OSC and CWR were higher than in the gulls from the land dump (1 and 2) (Italy) (Leonzio et al. 1986) and Rishiri Island, Japan (Agusa et al. 2005) and less than that of birds in South -Western (Poland) (Orlowski et al. 2008). Pb in OSC and CWR gulls muscle was higher than in those birds from the inland dump (1) (Italy) (Leonzio et al. 1986) and from Rishiri Island (Japan) (Agusa et al. 2005), and lower than those from inland dump (2) and coastal area (Italy) and International Airport, Queens County, New York (USA) (Gochfeld et al. 1996) and South -Western (Poland) (Orlowski et al. 2008) (Table 3).

$\mathrm{Pb}$ levels in the livers of OSC gulls were higher than in gulls in all regions compared in Table 3, except for the coastal area and inland dump (2) (Italy) (Leonzio et al. 1986) and South -Western (Poland) (Orlowski et al. 2008). Pb levels in gulls of CWR higher of Gull Island (Italy), Kent Island (Italy) (Elliott et al. 1992), International Airport, Queens County, New York (Gochfeld et al. 1996), Rishiri Island, Japan (Agusa et al. 2005) and lower of the Mana island, inland dump, Coastal area (Italy) (Leonzio et al. 1986; Elliott et al. 1992) and South -Western (Poland) (Orlowski et al. 2008) (Table 3).

According to other studies, Ni concentrations $>10 \mu \mathrm{g} / \mathrm{g}$ d.w. in kidney, and $>3 \mu \mathrm{g} / \mathrm{g}$ d.w. in the liver are toxic in wild birds (Outridge and Scheuhammer 1993 ). In this study, $100 \%$ and $90 \%$ Ni concentrations in liver of gulls in the OSC and CWR, and $80 \%$ Ni concentration in the kidney from OSC gulls were higher than the toxicity level.

$\mathrm{Pb}, \mathrm{Cd}$, and $\mathrm{Zn}$ levels in muscle, liver and kidney of gulls from the OSR and CWR were lower than gulls in Hara Biosphere reserve (Hoshyari et al. 2012), but levels of $\mathrm{Ni}$ in liver, kidney and muscles of gulls from the OSR and CWR were lower in liver, kidney and muscles in gulls from the Hara Biosphere reserve (Mansouri et al. 2012b). In the case of Ni, there was only one study to compare, and that was the level of Ni in tissues liver, kidney and muscle of Iranian gulls of Hara Biosphere reserve (Mansouri et al. 2012b); OSR and CWR gulls have much higher levels than this (Table 3). However, the levels of $\mathrm{Zn}, \mathrm{Cd}$ and $\mathrm{Pb}$ in the organs of birds in our study areas were lower than for other regions in the world; this indicates the low level of pollution in these regions compared to other regions in the world. The differences can be attributed to differences in bird diet (and associated contamination) (Savinov et al. 2003; Braune and Simon 2004; Schummer et al. 2011). The species compared in this study are all from the same family and probably do not have very different diets. This suggests that the difference in the level of pollution in the these regions are more affected by differences in environmental quality, that in turn has a major impact on the level of heavy metals in the foods consumed.

In the Beris region on the shores of the Oman Sea (where gull samples were taken), the level of heavy metals in the coastal sediments was as follows: $\mathrm{Zn}$ (mean = 79), $\mathrm{Ni}($ mean $=75.9), \mathrm{Pb}($ mean $=16)$ and $\mathrm{Cd}($ mean $=0.13)$, indicating that the sediments in the region were contaminated with $\mathrm{Ni}($ Hamzeh et al. 2013). The order of the elements in the sediments of this area was in order $\mathrm{Ni}>\mathrm{Zn}>>\mathrm{Pb}$ (Agah et al. 2016). Studies on oysters (Saccostrea cucullata) in this area of Chabahar coast also showed that $\mathrm{Ni}$ is higher than $\mathrm{Pb}$ (Einollahi Peer et al. 2010).

\subsection{Correlation between elements with weight, length and sex}

The significant, high negative correlation between the concentration of elements and the length and weight of gulls was related to the correlation between the concentration of $\mathrm{Cd}, \mathrm{Ni}, \mathrm{Pb}$ and $\mathrm{Zn}$ in the liver with weight $(\mathrm{r}=-0.691$ to $-0.785, \mathrm{P}<0.01)$, and to the correlation between the concentration of $\mathrm{Zn}$ and $\mathrm{Cd}$ in the liver and gull length $(-0.473, P<0.05)$ and $(r=-0.490, P<0.05)$ respectively (Table 4$)$. A significant, negative correlation was observed between the concentration of $\mathrm{Cd}, \mathrm{Ni}, \mathrm{Pb}$ and $\mathrm{Zn}$ in the brain with gull weight $(\mathrm{r}=-0.612$ to $-0.679, \mathrm{P}<0.01)$, and correlation with brain Ni with length $(-0.484$, $\mathrm{P}<0.05)$, brain $\mathrm{Zn}$ with length $(r=-0.483, \mathrm{P}<0.05)$, and brain $\mathrm{Pb}$ with length $(r=-0.445, \mathrm{P}<0.05)$ (Table 4). After liver and brain tissues, we observed a significant negative correlation between the concentration of elements in the kidney with weight in the gulls $(r=-0.553$ to -0.591 , $P<0.05)$. There was not a significant negative correlation between the concentration of $\mathrm{Ni}, \mathrm{Zn}$ and $\mathrm{Pb}$ in kidney with length, but there was a correlation between $\mathrm{Zn}$ kidney level with length $(r=-0.0542, \mathrm{P}<$ 0.05). There were no-significant correlations of any element in muscle with length and weight (Table 4). Similar correlations have been observed in other studies [50-52]. The level of Cd in the kidney of mallard (Anas platyrhynchos) was negatively related to length and weight (Alipour et al. 2016). There is also a negative correlation between liver weight and Zn concentration in the grey plover (Pluvialis squatarola) (Lucia et al. 2010). In lesser (Aythya affinis) and greater scaup (Aythya marila) the total carcass weight decreased with increased Zn (Takekawa et al. 2002).

Table 4 Correlation coefficient (r) between the concentrations of trace element with weight and length in slender-billed gull. 


\begin{tabular}{|c|c|c|}
\hline & Weight & Length \\
\hline Weight & 1 & 0.340 \\
\hline Length & 0.340 & 1 \\
\hline Zn liver & $-0.744^{* \star}$ & $-0.473^{*}$ \\
\hline $\mathrm{Pb}$ Liver & $-0.691^{\star \star}$ & NS \\
\hline Cd Liver & $-0.725^{\star \star}$ & $-0.490^{*}$ \\
\hline Ni Liver & $-0.785^{\star \star}$ & NS \\
\hline Zn Kidney & $-0.575^{\star *}$ & $-0.542^{*}$ \\
\hline Pb Kidney & $-0.591^{\star \star}$ & NS \\
\hline Cd Kidney & $-0.557^{*}$ & NS \\
\hline Ni Kidney & $-0.553^{*}$ & NS \\
\hline Zn Brian & $-0.679^{\star *}$ & $-0.483^{*}$ \\
\hline Pb Brian & $-0.669^{\star *}$ & $-0.445^{*}$ \\
\hline Cd Brian & $-0.634^{\star *}$ & NS \\
\hline Ni Brian & $-0.612^{\star *}$ & $-0.484^{*}$ \\
\hline Zn Muscle & NS & NS \\
\hline Pb Muscle & NS & NS \\
\hline Cd Muscle & NS & NS \\
\hline Ni Muscle & NS & NS \\
\hline
\end{tabular}

NS not significant $\quad * \mathrm{P}<0.05 \quad * *<0.01$

There are also gender-related physiological effects in birds. Heavy metals can have adverse effects on physiology of birds and cause defects in their reproductive process (Martin et al. 2003; Dauwe et al. 2004). High concentrations of Cd in birds causes damage to the kidneys, reduces the number of eggs, and changes their behavioral responses (Furness 1996). Other effects of Cd in birds include anemia, growth retardation, and testicular damage (Eisler 2000). Research has also shown that $\mathrm{Pb}$ toxicity reduces levels of plasma calcium, body weight, egg count, and reproductive success, kidney damage, and nervous system effects on synthesis of heme (Berny et al. 1994; Mateo et al. 2003). Although Cu and Zn are essential elements in the body of birds, high levels of these elements disrupt the reproductive system (Carpenter et al. 2004).

$\mathrm{Cd}$ and $\mathrm{Pb}$ are very toxic and non-essential elements in the body. If $\mathrm{Cd}$ is absorbed by the body through the digestive and pulmonary systems, it combines with a set of proteins to transport and store Cd in the liver of organisms (Szymczyk and Zalewski 2003). Pb can also have long-term effects on birds' organs and tissues if absorbed by birds (Beyer and Meador 2011). Zn is an essential element in the body of birds, but high levels of $\mathrm{Zn}$ can lead to poisoning and damage to the liver and pancreas tissues of birds (Kalisińska et al. 2007).

There are conflicting data regarding the level of heavy metals in the body of birds and its relationship with sex. Several studies found differences in metal concentrations between the sexes (Burger 1993; Swaileh and Sansur 2006), while other studies showed no difference in metals between males and females (Gochfeld and Burger 1987; Zaccaroni et al. 2003; Taggart et al. 2006). On the other hand, there are gender differences in the ability to remove trace metals. Females can excrete heavy metals from the body through eggs, which is not the case for males (Burger 1993; Mansouri et al. 2012a). Other differences may be due to nutritional differences between male and female birds (Gochfeld 1997). There are also gender-related differences in metallothionein, a metal-bound protein, which may account for gender differences in concentration of heavy metals (Hindell et al. 1999). We did observe significant gender differences between the Zn, Cd, and Ni content in liver in gulls (Table 5). These results suggest that there is sex-related difference in the gulls. Also, in the present study, except for Zn, Cd and Ni in liver, there wasn't evidence of significant differential accumulation between males and females (Table 5). This difference may be due to diet or to metabolic differences in the liver tissue of these birds. 
Table 5

Mean, median, minimum and maximum concentration $(\mu \mathrm{g} / \mathrm{g} \mathrm{d.w})$ in Liver, kidney, brain and muscle of of male and female of slender-billed

\begin{tabular}{|c|c|c|c|c|c|c|c|c|c|c|c|c|c|c|c|}
\hline & & $\begin{array}{l}\text { Zn } \\
\text { liver }\end{array}$ & $\begin{array}{l}\mathrm{Pb} \\
\text { liver }\end{array}$ & $\begin{array}{l}\text { Cd } \\
\text { liver }\end{array}$ & $\begin{array}{l}\mathrm{Ni} \\
\text { Liver }\end{array}$ & $\begin{array}{l}\text { Zn } \\
\text { kidney }\end{array}$ & $\begin{array}{l}\text { Pb } \\
\text { Kidney }\end{array}$ & $\begin{array}{l}\text { Cd } \\
\text { Kidney }\end{array}$ & $\begin{array}{l}\mathrm{Ni} \\
\text { Kidney }\end{array}$ & $\begin{array}{l}\text { Zn } \\
\text { Brian }\end{array}$ & $\begin{array}{l}\mathrm{Pb} \\
\text { Brian }\end{array}$ & $\begin{array}{l}\text { Cd } \\
\text { Brian }\end{array}$ & $\begin{array}{l}\mathrm{Ni} \\
\text { Brian }\end{array}$ & $\begin{array}{l}\text { Zn } \\
\text { Muscle }\end{array}$ & $\begin{array}{l}\mathrm{Pb} \\
\text { Musclı }\end{array}$ \\
\hline \multirow[t]{4}{*}{ Male } & Mean & $25.37 *$ & 2.32 & $2.14^{\star}$ & $11.95^{\star}$ & 9.34 & 0.98 & 0.71 & 4.52 & 51.71 & 4.88 & 3.14 & 0.60 & 7.77 & 0.79 \\
\hline & Median & 23.25 & 2.05 & 1.85 & 12.05 & 9.15 & 0.85 & 0.70 & 4.50 & 29.15 & 3.05 & 1.45 & 0.35 & 7.75 & 0.70 \\
\hline & Minimum & 7.60 & 0.70 & 0.60 & 3.30 & 5.60 & 0.50 & 0.40 & 2.60 & 10.60 & 0.80 & 0.80 & 0.1 & 6.90 & 0.60 \\
\hline & Maximum & 46.20 & 4.50 & 5.00 & 21.50 & 13.20 & 2 & 1 & 6.50 & 123.40 & 12.00 & 10.00 & 1.6 & 9 & 1.20 \\
\hline \multirow[t]{4}{*}{ Female } & Mean & $14.93^{*}$ & 1.48 & $1.16^{\star}$ & $7.36^{*}$ & 7.22 & 0.67 & 0.59 & 3.72 & 25.07 & 2.44 & 1.99 & 0.3 & 9.13 & 0.92 \\
\hline & Median & 13.55 & 1.25 & 1.00 & 6.35 & 7.00 & 0.70 & 0.60 & 3.60 & 22.25 & 2.00 & 1.80 & 0.3 & 8 & 0.80 \\
\hline & Minimum & 4.60 & 0.40 & .40 & 2.30 & 6.30 & 0.50 & 0.50 & 3.10 & 7.60 & 0.60 & 0.60 & 0.1 & 7.30 & .70 \\
\hline & Maximum & 26.00 & 3.00 & 2.00 & 14.00 & 8.50 & 0.80 & 0.70 & 5.00 & 51.50 & 5.50 & 4.20 & 0.5 & 14 & 1.50 \\
\hline
\end{tabular}

\section{Conclusion}

Levels of Zn. Cd, $\mathrm{Pb}$ and Zn in liver, kidney, brain and muscle of SBG (Chroicocephalus genei) in two different regions were investigated. A significant difference was observed between the concentrations of heavy metals in the brain and liver tissue of gulls from the OSC and CWR. The increases in heavy metal levels in the coastal region may be due to the effluent from shipbuilding activities and municipal sewage, as well as from soil erosion from the river upstream of the region. In the OSC region, the correlation among heavy metals was high in one tissue, and in the CWR, except for muscle tissue, heavy metals were highly correlated with each other. There was also a significant gender difference between $\mathrm{Zn}, \mathrm{Cd}$ and $\mathrm{Ni}$ in liver and $\mathrm{Zn}$ and $\mathrm{Pb}$ in kidney that may be due to diet differences or to differences in body metabolism in the kidney and liver tissue of these birds. This suggests that heavy metal production sources are common in the OSC region. Toxicity levels for $\mathrm{Pb}$ were exceeded for $40 \%$ of the gulls collected along the Oman Sea coast. Toxicity levels were exceeded for Ni in $100 \%$ and $90 \%$ of the livers of gulls from the Oman Sea coast and Chahnimeh water reservoirs respectively, and for $80 \%$ of the gull kidney tissue from Oman Sea coast. This study found that liver tissue is the best indicator for measuring heavy metals and indicating environmental differences in this bird species.

\section{Declarations}

Author contributions: Conceptualization, Formal analysis, data curation, investigation, Reza Dahmardeh Behrooz; methodology, review \& editing Joanna Burger. All authors have read and agreed to the published version of the manuscript.

Availability of data and materials The authors declared that the data and materials for this work are available.

Conflict of interest The authors declared that there is no conflict of interest among them. All the authors read and approved the manuscript.

Ethics approval and consent to participate All procedures performed in studies involving collection birds and people who participated in this study were in accordance with the ethical standards of the institutional and/or national research committee University of Zabol with reference number IR.UOZ.REC.1399.005.

Consent for publication I understand that the text and any pictures published in the article will be freely available on the internet and may be seen by the general public. The pictures, and text may also appear on other websites or in print, may be translated into other languages or used for commercial purposes.

Funding Information: This work was funded by the University of Zabol, Project code PR-UOZ 99-4.

\section{References}

1. Agah H, Saleh A, Bastami KD, Fumani NS (2016) Ecological risk, source and preliminary assessment of metals in the surface sediments of Chabahar Bay, Oman Sea. Mar Pollut Bull 107:383-388. https://doi.org/10.1016/j.marpolbul.2016.03.042

2. Agusa T, Matsumoto T, Ikemoto T, et al (2005) Body distribution of trace element in Black-Tailed gull from Rishiri island, Japan: Age depended accumulation and transfer to feathers and eggs. Environ Toxicol Chem 24:2107. https://doi.org/10.1897/04-617R.1

3. Alipour H, Solgi E, Majnouni F (2016) Concentrations of Heavy Metals in tissues of the Mallard Anas platyrhynchos in Kanibarazan, northwestern Iran. Podoces 11:35-42

4. Amini-Ranjbar GH, Miraki GH (2006) Evaluation of quantity and quality of the Chabahar bay. Sistan Baluchestan Univ 7-9

5. Barbieri E, de Andrade Passos E, Filippini A, et al (2010) Assessment of trace metal concentration in feathers of seabird (Larus dominicanus) sampled in the Florianópolis, SC, Brazilian coast. Environ Monit Assess 169:631-638

6. Berny PJ, Cote LM, Buck WB (1994) Relationship between soil lead, dust lead, and blood lead concentrations in pets and their owners: evaluation of soil lead threshold values. Environ Res 67:84-97

7. Beyer WN, Dalgarn J, Dudding S, et al (2004) Zinc and Lead Poisoning in Wild Birds in the Tri-State Mining District (Oklahoma, Kansas, and Missouri). Arch Environ Contam Toxicol 48:108-117. https://doi.org/10.1007/s00244-004-0010-7

Page 9/12 
8. Beyer WN, Meador JP (2011) Environmental contaminants in biota: interpreting tissue concentrations. CRC Press

9. Braune BM, Scheuhammer, M. A (2008) Trace element and metallothionein concentrations in seabirds from the Canadian arctic. Environ Toxicol Chem 27:645-651. https://doi.org/10.1897/07-269.1

10. Braune BM, Simon M (2004) Trace elements and halogenated organic compounds in Canadian Arctic seabirds. Mar Pollut Bull 48:986-992

11. Burger J (1993) Metals in avian feathers: bioindicators of environmental pollution. Rev Env toxicol 5:203-311

12. Burger J, Gochfeld M (2016) Habitat, population dynamics, and metal levels in colonial waterbirds: a food chain approach. CRC Press

13. Carpenter JW, Andrews GA, Beyer WN (2004) Zinc toxicosis in a free-flying trumpeter swan (Cygnus buccinator). J Wildl Dis 40:769-774

14. Clark AJ, Scheuhammer AM (2003) Lead poisoning in upland-foraging birds of prey in Canada. Ecotoxicology 12:23-30

15. Dahmardeh Behrooz R, Sahebi S, Majnoni F, et al (2013) Mercury contamination in commercial fresh and salt water fish of the Zabol Chahnimeh reservoirs and the Gulf of Oman (Iran). Food Addit Contam Part B 6:175-180. https://doi.org/10.1080/19393210.2013.779322

16. Dauwe T, Janssens E, Kempenaers B, Eens M (2004) The effect of heavy metal exposure on egg size, eggshell thickness and the number of spermatozoa in blue tit Parus caeruleus eggs. Environ Pollut 129:125-129

17. Degernes LA (2008) Waterfowl toxicology: a review. Vet Clin North Am Exot Anim Pract 11:283-300

18. Einollahi Peer F, Safahieh A, Sohrab, Dadollahi A, Pakzad Tochi S (2010) Heavy Metal Concentrations in Rock Oyster Socostrea Cucullata From Iranian Coasts of the Oman Sea. Trakia J Sci 8:79-86

19. Eisler R (2000) Handbook of chemical risk assessment: health hazards to humans, plants, and animals, three volume set. CRC press

20. Elliott JE, Scheuhammer AM, Leighton FA, Pearce PA (1992) Heavy metal and metallothionein concentrations in Atlantic Canadian seabirds. Arch Environ Contam Toxicol 22:63-73. https://doi.org/10.1007/BF00213303

21. Erwin RM, Custer TW (2000) Herons as indicators

22. Furness RW (1996) Cadmium in birds. Environ Contam Wildl Interpret tissue Conc Lewis, Boca Rat 389-404

23. Gochfeld M (1997) Factors influencing susceptibility to metals. Environ Health Perspect 105:817-822

24. Gochfeld M, Belant JL, Shukla T, et al (1996) Heavy metals in laughing gulls: gender, age and tissue differences. Environ Toxicol Chem 15:2275-2283

25. Gochfeld M, Burger J (1987) Heavy metal concentrations in the liver of three duck species: influence of species and sex. Environ Pollut 45:1-15

26. Gomez G, Baos R, Gomara B, et al (2004) Influence of a Mine Tailing Accident Near Dooana National Park (Spain) on Heavy Metals and Arsenic Accumulation in 14 Species of Waterfowl (1998 to 2000). Arch Environ Contam Toxicol 47:521-529. https://doi.org/10.1007/s00244-004-0189-z

27. Grue CE, Hoffman DJ, Beyer WN, Franson LP (1986) Lead concentrations and reproductive success in European starlings Sturnus vulgaris nesting within highway roadside verges. Environ Pollut Ser A, Ecol Biol 42:157-182

28. Hamzeh MA, Shah-hosseini M, Naderi Beni A (2013) Effect of fishing vessels on trace metal contamination in sediments of three harbors along Iranian Oman Sea coast. Environ Monit Assess 185:1791-1807. https://doi.org/10.1007/s10661-012-2668-z

29. Havera SP, Wood SG, Georgi MM (1992) Blood and tissue parameters in wild mallards redosed with lead shot. Bull Environ Contam Toxicol 49:238-245

30. Hindell MA, Brothers N, Gales R (1999) Mercury and cadmium concentrations in the tissues of three species of southern albatrosses. Polar Biol 22:102108

31. Hoshyari E, Pourkhabbaz A, Mansouri B (2012) Contaminations of Metal in Tissues of Siberian Gull Larus heuglini: Gender, Age, and Tissue Differences. Bull Environ Contam Toxicol 89:102-106. https://doi.org/10.1007/s00128-012-0655-2

32. Hulse M, Mahoney JS, Schroder GD, et al (1980) Environmentally acquired lead, cadmium, and manganese in the cattle egret, Bubulcus ibis, and the laughing gull, Larus atricilla. Arch Environ Contam Toxicol 9:65-77

33. Janaydeh M, Ismail A, Zulkifli SZ, et al (2016) The use of feather as an indicator for heavy metal contamination in house crow (Corvus splendens) in the Klang area, Selangor, Malaysia. Environ Sci Pollut Res 23:22059-22071. https://doi.org/10.1007/s11356-016-7223-y

34. Kalisinska E (2000) Lead and other heavy metals in the brain of geese hunted in the vicinity of Slonsk, Poland. Biol Bull Poznań 37:

35. Kalisińska E, Salicki W, Kavetska KM, Ligocki M (2007) Trace metal concentrations are higher in cartilage than in bones of scaup and pochard wintering in Poland. Sci Total Environ 388:90-103

36. Kim EY, Ichihashi H, Saeki K, et al (1996) Metal accumulation in tissues of seabirds from Chaun, northeast Siberia, Russia. Environ Pollut $92: 247-252$. https://doi.org/10.1016/0269-7491(96)00007-3

37. Leonzio C, Fossi C, Focardi S (1986) Lead, Mercury, Cadmium and Selenium in Two Species of Gull Feeding on Inland Dumps, and in Marine areas. 57:121-127

38. Lucia M, André J-MM, Gontier K, et al (2010) Trace element concentrations (mercury, cadmium, copper, zinc, lead, aluminium, nickel, arsenic, and selenium) in some aquatic birds of the Southwest Atlantic Coast of France. Arch Environ Contam Toxicol 58:844-853. https://doi.org/10.1007/s00244009-9393-9

39. Malinga M, Szefer P, Gabrielsen GW (2010) Age, sex and spatial dependent variations in heavy metals levels in the Glaucous Gulls (Larus hyperboreus) from the Bjørnøya and Jan Mayen, Arctic. Environ Monit Assess 169:407-416. https://doi.org/10.1007/s10661-009-1183-3

40. Mansouri B, Babaei H, Hoshyari E, et al (2012a) Assessment of Trace-Metal Concentrations in Western Reef Heron (Egrettagularis) and Siberian Gull (Larusheuglini) From Southern Iran. Arch Environ Contam Toxicol 63:280-287

41. Mansouri B, Babaei H, Hoshyari E, et al (2012b) Assessment of Trace-Metal Concentrations in Western Reef Heron (Egretta gularis) and Siberian Gull (Larus heuglini) From Southern Iran. Arch Environ Contam Toxicol 63:280-287. https://doi.org/10.1007/s00244-012-9762-7 
42. Martin MB, Reiter R, Pham T, et al (2003) Estrogen-like activity of metals in MCF-7 breast cancer cells. Endocrinology 144:2425-2436

43. Mateo R, Beyer WN, Spann J, et al (2003) Relationship between oxidative stress, pathology, and behavioral signs of lead poisoning in mallards. J Toxicol Environ Heal Part A 66:1371-1389

44. Morris CM, Candy JM, Oakley AE, et al (1992) Histochemical distribution of non-haem iron in the human brain. Cells Tissues Organs 144:235-257

45. NERGIZ H (2019) ASSESSMENT OF HEAVY METAL CONCENTRATION IN FEATHERS OF ARMENIAN GULL (LARUS ARMENICUS BUTURLIN, 1934) AND WATER SAMPLES OF HAZAR LAKE, TURKEY. Appl Ecol Environ Res 17:10221-10227. https://doi.org/10.15666/aeer/1704_1022110227

46. Nicholson JK (1981) The comparative distribution of zinc, cadmium and mercury in selected tissues of the herring gull (Larus argentatus). Comp Biochem Physiol Part C Comp Pharmacol 68:91-94. https://doi.org/10.1016/0306-4492(81)90042-3

47. Orlić I, Tang SM (1999) Elemental depth profiles in marine sediments of Singapore coastal waters. Nucl Instruments Methods Phys Res Sect B Beam Interact with Mater Atoms 150:291-297

48. Orlowski G, Polechonski R, Dobicki W, Zawada Z (2008) Black-Headed gull Larus Ridibundus L . Nesting in the Dam Reservoir in south-western Poland. Polish J Ecol 55:783-793

49. Outridge PM, Scheuhammer AM (1993) Bioaccumulation and toxicology of nickel: implications for wild mammals and birds. Environ Rev 1:172-197

50. Rice DC (1992) Behavioral effects of lead in monkeys tested during infancy and adulthood. Neurotoxicol Teratol 14:235-245

51. Savinov VM, Gabrielsen GW, Savinova TN (2003) Cadmium, zinc, copper, arsenic, selenium and mercury in seabirds from the Barents Sea: levels, interspecific and geographical differences. Sci Total Environ 306:133-158. https://doi.org/10.1016/S0048-9697(02)00489-8

52. Scheuhammer AM (1987) The chronic toxicity of aluminium, cadmium, mercury, and lead in birds: a review. Environ Pollut 46:263-295

53. Schummer ML, Petrie SA, Badzinski SS, et al (2011) Elemental contaminants in livers of mute swans on Lakes Erie and St. Clair. Arch Environ Contam Toxicol 61:677-687

54. Sileo L, Nelson Beyer W, Mateo R (2003) Pancreatitis in wild zinc-poisoned waterfowl. Avian Pathol 32:655-660

55. Swaileh KM, Sansur R (2006) Monitoring urban heavy metal pollution using the House Sparrow (Passer domesticus). J Environ Monit 8:209-213

56. Szefer P, Falandysz J (1987) Trace metals in the soft tissues of scaup ducks (Aythya marila L.) wintering in Gdańsk Bay, Baltic Sea. Sci Total Environ 65:203-213

57. Szymczyk K, Zalewski K (2003) Copper, Zinc, Lead and Cadmium Content in Liver and Muscles of Mallards (Anas Platyrhychnos) and Other Hunting Fowl Species in Warmia and Mazury in 1999-2000. Polish J Environ Stud 12:

58. Taggart MA, Figuerola J, Green AJ, et al (2006) After the Aznalcóllar mine spill: Arsenic, zinc, selenium, lead and copper levels in the livers and bones of five waterfowl species. Environ Res 100:349-361. https://doi.org/10.1016/j.envres.2005.07.009

59. Taggart MA, Green AJ, Mateo R, et al (2009) Metal levels in the bones and livers of globally threatened marbled teal and white-headed duck from El Hondo, Spain. Ecotoxicol Environ Saf 72:1-9. https://doi.org/10.1016/j.ecoenv.2008.07.015

60. Takekawa JY, Wainwright-De La Cruz SE, Hothem RL, Yee J (2002) Relating body condition to inorganic contaminant concentrations of diving ducks wintering in coastal California. Arch Environ Contam Toxicol 42:60-70

61. Ullah K, Hashmi MZ, Malik RN (2014) Heavy-metal levels in feathers of cattle egret and their surrounding environment: a case of the Punjab Province, Pakistan. Arch Environ Contam Toxicol 66:139-153

62. Vaneeden PH, Schoonbee HJ (1992a) CONCENTRATIONS OF HEAVY-METALS IN ORGANS AND TISSUES OF THE REDKNOBBED COOT. Ostrich 63:165171

63. Vaneeden PH, Schoonbee HJ (1992b) Concentration of Heavy metals in organs and tissues of the Redknobbed Coot. Ostrich 63:165-171

64. Vizuete J, Pérez-López M, Míguez-Santiyán MP, Hernández-Moreno D (2018) Mercury (Hg), Lead (Pb), Cadmium (Cd), Selenium (Se), and Arsenic (As) in Liver, Kidney, and Feathers of Gulls: A Review. In: Reviews of Environmental Contamination and Toxicology. pp 85-146

65. Zaccaroni A, Amorena M, Naso B, et al (2003) Cadmium, chromium and lead contamination of Athene noctua, the little owl, of Bologna and Parma, Italy. Chemosphere 52:1251-1258

66. Zhang J, Han L, Ji Y, et al (2018) Heavy metal investigation and risk assessment along the Le'An River from non-ferrous metal mining and smelting activities in Poyang, China. J Environ Biol 39:536-545

\section{Figures}



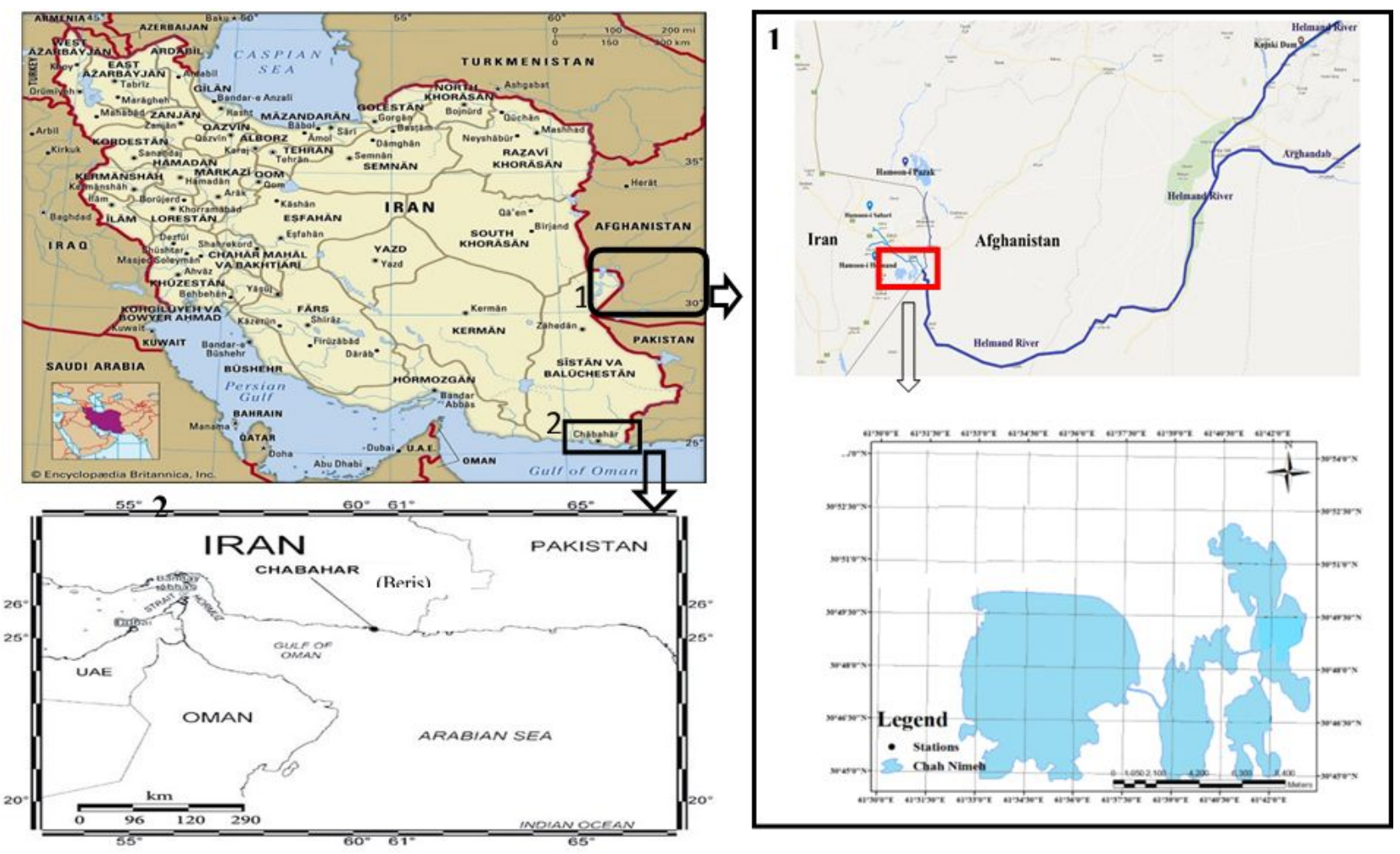

Figure 1

Map showing sampling location slender-billed gull Note: The designations employed and the presentation of the material on this map do not imply the expression of any opinion whatsoever on the part of Research Square concerning the legal status of any country, territory, city or area or of its authorities, or concerning the delimitation of its frontiers or boundaries. This map has been provided by the authors.

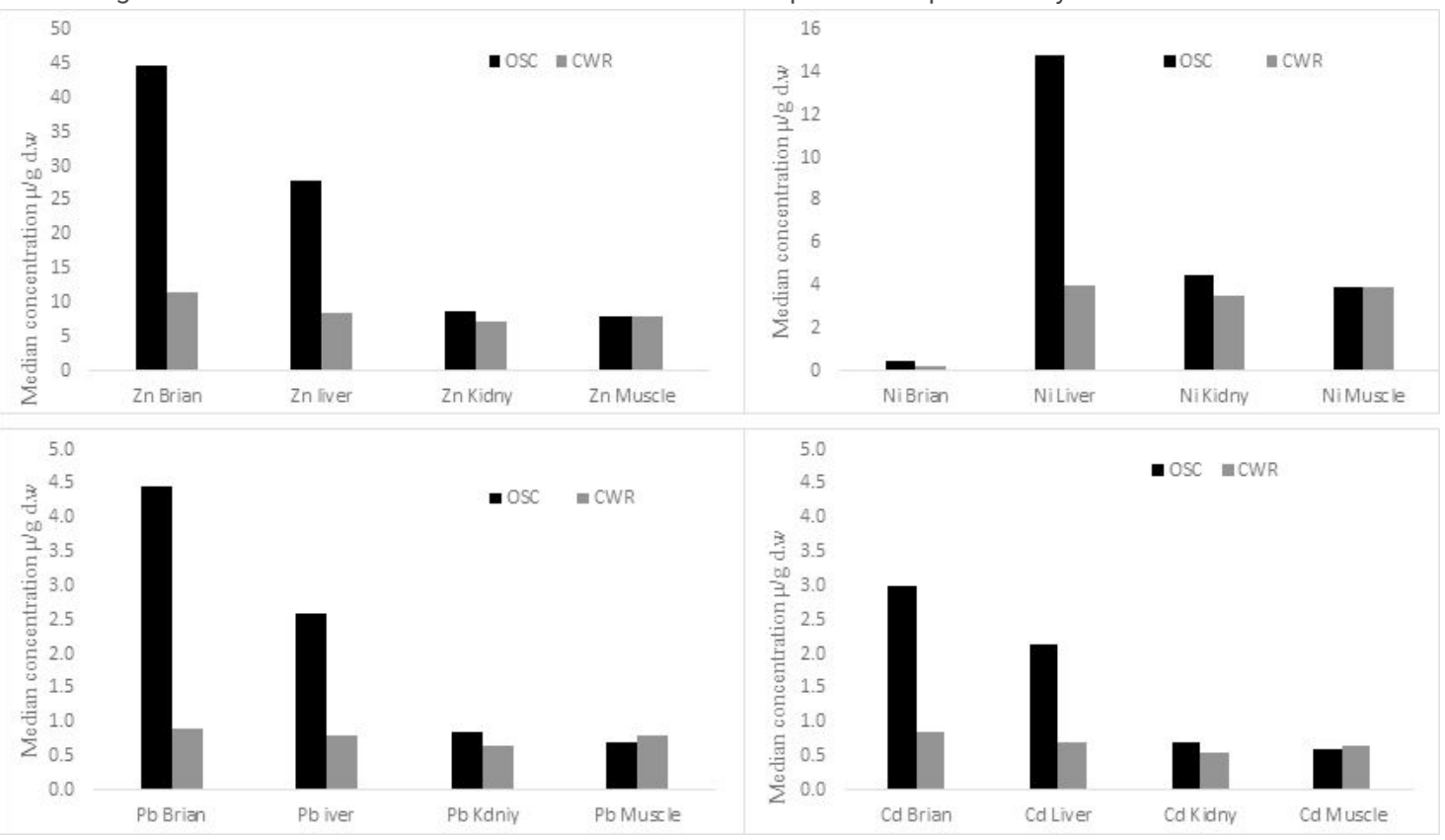

Figure 2

Median concentration ( $\mu \mathrm{g} / \mathrm{g} \mathrm{d.w}$ ) Zn, Ni, Cd and $\mathrm{Pb}$ in liver, kidney, brain and muscle slender-billed gull 